Електронне наукове фахове видання з економічних наук "Modern Economics», №22 (2020), 99-107 https://modecon.mnau.edu.ua | ISSN 2521-6392

Tkachuk Iryna, PhD, Associate Professor, Affiliated Honorary Research Fellow at Fil. Dr. Jan-U. Sandal Institute, Norway

ORCID ID: 0000-0001-5953-3109

e-mail: provost@janusandal.no

\title{
Civil Society Institutions: Essence and Role
}

\begin{abstract}
Introduction. There is a considerable economic effect of the activities of civil society institutions and programs that promote its development in the economically developed countries of the world. In Ukraine, the situation is significantly different, which is due to the effectiveness of civil society institutions, as well as their perception by the population, state and business.
\end{abstract}

Purpose. The purpose of the article is to explore the features of the functioning of civil society institutions, their essence and role in the society.

Results. The article considers various scientific approaches to the interpretation of the category "civil society institution", and they are used to formulate the author's approach. Accordingly, civil society institutions are voluntary, self-governed organizations, whether formal or informal, that unite individuals and legal entities around a common idea or purpose other than making a profit. It is substantiated that the list of institutions united under the name of "civil society institutions" should include political parties, as they are entities that unite citizens around a common idea and values and, in the process of their statutory activities, they provide services to the population and promote its communication with the authorities. It is substantiated that the institutions of civil society perform 4 main functions: oppositional, creative, protective, auxiliary, which are realized by solving the tasks assigned by society to these institutions. The article considers approaches of four authoritative international organizations to the selection of the principles of formation and activity of civil society institutions. It is determined that the following principles are common to these organizations: the principle of voluntary creation; focus on public benefit; cooperation with other entities to achieve the goals; accountability; equality of rights and freedoms; and legal protection of activities.

Conclusions. Civil society institutions are voluntary, self-governed organizations, whether formal or informal, that bring together individuals and legal entities around a common idea or purpose other than making a profit. All civil society institutions have specific functions, tasks, principles of formation and activities that make them different from other similar organizations. The development of civil society creates significant economic and social effects in the developed countries of the world, which are also worth striving for in Ukraine, but this is still a long way off. The reason for this situation lies in the shortcomings of the civil society in Ukraine due to its hybrid development. These shortcomings of Ukrainian civil society can be eliminated with a developed network of civil society institutions in society. Such development can be achieved by forming a high-quality and effective strategy to promote the development of civil society at the state level and promote the activities of civil society institutions among the population.

Keywords. civil society; civil society institutions; functions of civil society institutions; principles of civil society.

\section{Удк 334.7}

Ткачук І. Я., кандидат економічних наук, доцент, асоційований науковий співробітник Інституту Яна-У. Сандала, Норвегія

\section{Інститути громадянського суспільства: зміст та роль}

Анотація. В економічно розвинених країнах світу простежується значний економічний ефект від діяльності інститутів громадянського суспільства та програм сприяння його розвитку. В Україні ситуація суттєво відрізняється, що пов'язано як з ефективністю діяльності інститутів громадянського суспільства, так $і$ з їх сприйняттям населенням, державою та бізнесом. Метою публікації є виокремлення особливостей функціонування інститутів громадянського суспільства, їх змісту та ролі в суспільстві. У статті розглянуто різні наукові підходи до трактування категорії «інститут громадянського суспільства», у результаті чого сформульовано авторський підхід, відповідно до якого інститути громадянського суспільства - це добровільні, самоврядні організації формального чи неформального характеру, що об'єднують фізичних і юридичних осіб навколо спільної ідеї чи мети діяльності, відмінної від отримання прибутку. Обгрунтовано, що до переліку інститутів, що об'єднані під назвою «інститутів громадянського суспільства» слід відносити і політичні партії як суб'єкти, які об'єднують громадян навколо спільної ідеї та цінностей та в процесі власної статутної діяльності надають послуги населенню та сприяють його комунікації з владою. Обгрунтовано, що інститути громадянського суспільства виконують 4 основні функції: опозиційну, творчу, захисну, допоміжну, які реалізовуються шляхом розв'язання завдань, покладених суспільством на ці інститути. Розглянуто підходи чотирьох авторитетних міжнародних організацій до виділення принципів утворення та діяльності інститутів громадянського суспільства. Визначено, що спільними для цих організацій є такі принципи

Acknowledgment. This scientific article was produced at the Fil. Dr. Jan-U. Sandal Institute, Finstadjordet, Norway under the supervision of Prof. Fil. Dr. Jan-Urban Sandal, Executive Director and Owner at the Fil. Dr.Jan-U. Sandal Institute (Excellence in Science and Education). The paper was produced with the support of Summit Fund (ES-01-A-Sientific Entrepreneur Grant) awarded by Fil. Dr. Jan-U. Sandal Institute 
як принципи добровільності створення; орієнтації на суспільну вигоду; співпраця з іншими суб'єктами задля досягнення мети діяльності; підзвітності; рівності прав та свобод; правовий захист діяльності.

Ключові слова: громадянське суспільство; інститути громадянського суспільства; функції інститутів громадянського суспільства; принципи громадянського суспільства.

Formulation of the problem. In the economically developed countries around the world, there is a significant economic effect of activities of civil society institutions and programs to promote the development of civil society (hereinafter - CS). In particular, the analytical report "On the state of development of the CS of Ukraine", prepared by the National Institute for Strategic Studies in 2012, provides analytical data that characterize the contribution of civil society institutions in the development of the world economy [26].

- Non-governmental organizations (hereinafter NGOs) create an average of $3 \%$ to $9 \%$ of GDP in developed countries (for example, $5 \%$ in Belgium and $7.9 \%$ in Canada);

- in the EU countries, $4.4 \%$ to $14 \%$ of the able-bodied population or at least five out of every hundred are employed in the public sector;

- in the European Union countries, there are 10 times more people working in the public sector than in the light industry, and 5 times more than in the food industry;

- in the countries of Central and Eastern Europe, NGOs involve three times more internal and external investments in the social sphere than the state and municipal social institutions;

- the contribution of NGOs to the GDP of the EU countries is growing twice as fast as the contribution of light industry;

- the civil society in total is the seventh economy of the world as to the GDP (1.3 trillion conventional units, equal to the GDP of France or the United Kingdom);

- the civil society has created more than 25 million paid jobs in the world (the largest multinational corporation creates 3.5 million jobs);

$-60 \%$ of the civil society representatives (including volunteers) are engaged in providing services, $40 \%$ of them focus on social, medical and educational services.

It is expected that nowadays the role of the civil society organizations (hereinafter - CSOs) in the development of the economies of the world countries has increased; however, the Ukrainian CS is not characterized by such a contribution to the development of the national economy.

As the role of CS is not fully disclosed in Ukraine, it is necessary to look for the reasons in its institutions, as the activity of their network reflects the development and effectiveness of CS itself. Therefore, first, it is important to understand which organizations are united by the name of CSO and how they can be classified.

Analysis of recent research and publications. The existence and development of CS have always been the subject of discussion among scholars, politicians, and journalists in independent Ukraine. Such discussions became most intense during the peaks of democracy (early 1990 the Orange Revolution of 2004-2005, the period of the Revolution of Dignity of 2013-2014, etc.).

Ukrainian and foreign scientists have paid much attention to these issues in their works. It is worth noting that the following foreign scientists made a special contribution to the study of CS: Jeffrey C. Alexander, E. Gellner, M. Edwards, A. Croissant, H. Lauth, D. Lewis, W. Merkel, N. Rosenblum, Ch. Spurk, A. Tocqueville, J. Habermas, G. Shade and J. Jung.

The following Ukrainian researchers have also investigated these issues in their works: A. Karas, V. Kopeichykov, I. Lievin, V. Morhun, L. Novoskoltseva, Yu. Pavlenko, M. Pavlovskyi, O. Polishchuk, O. Pukhkal, P. Rabinovych, T. Rozova, N. Filyk, L. Khomiakov and O. Chuvardynskyi.

However, despite the achievements of the abovementioned scholars, it should be recognized that the topic of CS is not fully studied, as scientists have paid most attention to the study of the problem as a whole or its individual aspects, including historical, political, legal, social, cultural and others. On the other hand, the institutions of civil society and their role in society have not been studied enough.

Formulation of research goals. The purpose of the article is to explore the features of the functioning of civil society institutions, their essence and role in society.

Outline of the main research material. In Ukraine and internationally, there are a lot of approaches to the interpretation of the concept of CSOs yet. Therefore, let us explore different approaches to defining this concept.

The term "civil society institution" (hereinafter - CSI) or "civil society organization" (CSO) is so widely used in everyday life that today there are different approaches to its definition. Thus, Ukrainian Helsinki Human Rights Union, summarizing different approaches to the interpretation of this concept, identifies several approaches [34]:

- CSIs are entities that in the process of their activities form public relations aimed at establishing CS;

- CSIs are institutions that combine the rules of constitutional law and other branches that regulate public relations in the relevant field and are components of a multidimensional system of constitutional law of Ukraine;

- CSI is a generic name for all ordered and structured manifestations of $\mathrm{CS}$, etc.

From a legal point of view, all these approaches deserve attention and at the same time, none of them can be regarded as the absolute truth. However, given that the subject of our study is economic relations, we consider it necessary to consider those approaches to the interpretation of CSIs, which are based on the institutional essence, in more detail.

Ukrainian science is not characterized by a large number of studies based on the analysis of the functioning 
of $\mathrm{CS}$, and accordingly, the practice does not provide experience for defining the concept of CSOs. However, let us consider the approaches to the interpretation of CSOs (CSIs) that it suggests to be applicable.

Thus, O. Lotiuk defines a CSI as a certain organism (which has its own hierarchical structure), the members of which have a certain standardized pattern of behaviour, while the organism itself is characterized by a certain standardized activity and a certain mechanism, i.e. a set of rules governing the structure of an organization and certain activity" [20, p. 32]. Thus, this scholar emphasizes the importance of the unifying components of the CS, among which the most important are the behavioural model of CSI members and the set of rules that determine it. This approach, in our opinion, is of interest from an organizational point of view, but it does not take into account such an important element of CSO activity as its purpose.

Contrary to O. Lotiuk's approach, V. Kuprii suggests regarding CSOs as "voluntary self-governed social structures that implement legal goals regarding personal non-property rights, do not subject to management by state bodies and do not perform the functions of such bodies" [19]. Thus, the above-mentioned scholar determines the importance not only of the legitimacy of a CSI, but also of its legality. S. Soliar also emphasizes the need to strike a balance between the legitimacy and legality of the CS, as "...the expansion of legitimacy encourages the state to adopt new regulations that legalize prior illegal activities of CSIs" [29, p. 936].

It is worth paying attention to the statement of I. Ziatkovskyi, who in 2005 stated the following: "NGOs (public and other associations of citizens) are specific business entities that characterize the level of democratization of society" [16, p. 132-133].

In this point of view it should be mentioned that CSIs reflect the mood of the population that prevails in the state. Respectively, they are dynamic, constantly changing and evolving. For example, 30 years ago in Ukraine, which at that time was a part of the former Soviet Union, was a developed network of CSIs. However, due to the restrictions created by the Center located in Moscow, their activities were not oppositional, but they were represented by organizations united the population only by cultural and sports interests (sports clubs, chess clubs, etc.). Today, CSIs represent the full range of activities, including promoting democracy and civic education.

Foreign scholars are characterized by much greater diversity in the approaches to the definition of CSIs.

UNDP provides the following definition: CSIs are nonstate actors whose purpose is neither to make profit nor to seek power. After all, they unite people to achieve common goals and interests. As we can see, UNDP focuses exclusively on the purpose of CSOs, ignoring any other characteristic features.

At the request of the World Bank, scientists at Oxford University have published a study on the functioning of the CS. According to it, CSO is a concept that covers a wide range of formal and informal networks and organizations, including non-governmental organizations and public organizations, neighbourhood and family networks [3]. By developing such an approach, British scholars have erased the limits of formalizing the CS and at the same time emphasized the importance of social capital for its development.

CS researcher, Johns Hopkins University professor Lester M. Salamon generalizes CSIs as private, non-profit, self-governed, voluntary organizations [9]. This definition, in our opinion, contains an almost exhaustive list of characteristics that a CSI has, in particular: the conditions of association of members - voluntariness, purpose - to achieve goals other than commercial interest, features of the organization and decision-making - self-government.

A. Uvarov, a representative of the Russian school of thought that studies the functioning of the CS, argues that CSIs are exclusively voluntary associations, the activities of which are formalized by the state [33, p. 2], that is, they are legal. His colleagues N. Lapin and I. Usvatov also share this point of view. In particular, N. Lapin notes that in order for a certain voluntary formation to become an element of the CS, it must be institutionalized by the state, and I. Usvatov clarifies that the institutionality and even the existence of state will is beyond doubt in modern science [34, p. 82-83].

Given the differences in all the previously mentioned approaches to the interpretation of the concept of CSI, it is interesting to separate all approaches to the definition of CSIs, just as S. Soliar has done. In order to study approaches to defining the CSIs, he has divided them into two broad groups: those that view CSIs as voluntary organizations legalized by the state, and those based on the belief that CSOs have the right to determine their own forms of existence [30, p. 936]. We consider it appropriate to apply this approach, as it reflects the substantive differences in the role of CSIs that they can play in society and the economy.

It is important to clarify that most supporters of the "state" approach to the definition of the CSIs are representatives of Russian scientific thought, while those who believe that such an approach functionally limits the activities of the CS, belong to the representatives of Western scientific thought. It should be noted that most Ukrainian scholars also share the view that the exclusion of organizations the activities of which are not illegal from the point of view of law, but prohibited by the state, from the CSOs significantly limits the role of the CS in the society and limits the democracy in such states.

Summarizing all of the above, let us formulate our own interpretation of the studied categories. Therefore, we believe that CSIs are voluntary, self-governed organizations of a formal or informal nature, uniting individuals and legal entities around a common idea or purpose of activities other than profit.

However, it should be noted that in the given study, we consider those CSIs the activities of which are of a formal nature, as the formalization of public associations 
gives them the right to participate in the redistribution of financial resources of economic entities.

The study of the finances of the CS involves a clear understanding of those entities that are united by the title "CSI".

For the first time, the legislative standardization of the concept of "CSI" in Ukrainian practice was carried out in 2008 in the Procedure for promoting public examination of the activities of executive branch [25]. According to this Procedure, today (taking into account all further changes to it) CSIs unite public associations, trade unions and their associations, creative unions, associations of employers, charitable and religious organizations, community organizations, non-state media and other non-business entities and institutions legalized in accordance with the law [25].

This Procedure in its modern version is considered almost universal and covers almost the entire range of organizations that can be defined by the concept of CSI. However, it does not include political parties (hereinafter - PPs), the affiliation with the CSIs of which is contradictory because the ultimate goal of their activities is to gain and retain power. Bearing all of this in mind, we will look into the opinion of scientists on whether it is worth to include PPs in CSIs or not.

According to the Law of Ukraine "On Political Parties", a PP is a registered according to the law, voluntary association of citizens - supporters of a national program of social development, which aims to promote the formation and expression of political will of citizens and participates in elections and other political events [26].

For the most part, Ukrainian scientists classify PPs as CSIs. Thus, R. Moshynskyi attaches an important role to PPs as institutions that, "regardless of ideology, social base, structure, number of participants, etc. in their program documents, and through practical activities, pay considerable attention to national security as an objective condition for PPs" [23, p. 184-192].

In particular, M. Beliaieva also regards PPs as CSOs, emphasizing that they are an element of a constant channel of public communication with the authorities, playing an important role in resolving social conflicts peacefully [11].

At the same time, O. Mazur believes that PPs are CSOs, which is considered a factor in modernizing the electoral system [22]. Thus, this researcher considers PPs as those that directly contribute to the development of democracy in the state.

In addition, $A$. Chernoivanenko identifies a number of social functions performed by PPs (political representation of social interests, social integration, participation in the development, formation and implementation of the state policy, political socialization, and the formation of public opinion) [36].

The opinion expressed by V. Grabovsky and O. Mishchan is somewhat different. They believe that only those PPs that have not come to power to be CSIs [13, p. 361-365]. We want to clarify that, in our opinion, on the one hand, CSIs are those PPs that are not represented in government, because they can perform an oppositional function to the government, however, and on the other, those PPs the representatives of which have joined one or another branch of government are excluded from the CS. However, it should be clarified that the PPs that came to power do not cease to perform their basic functions; they continue to be aimed at meeting the needs of the population, can represent its interests at the highest level, form and express the political will of citizens.

Thus, we can summarize that for the most part Ukrainian scientists tend to include PPs in CSIs. However, given that the world science that deals with the study of the CS has a much longer history, let us consider the approaches of foreign scientists to this matter.

As mentioned earlier, UNDP, in its approach to the definition of CSOs, excludes those PPs the activities of which are clearly aimed at gaining and retaining power. In addition, UNDP provides an exhaustive list of organizations (or their associations) that are united by the concept of "CSOs", including public organisations, professional associations, foundations, independent research institutes, community organizations, religious organizations, social movements and trade unions. We should point out that due to the much lower level of development of science and practice related to the CS, most of these organizations (except for religious organizations) operate in the form of public organisations in Ukraine.

At the same time, the approach of scientists from the Office of democracy and governance, Bureau for democracy, Conflict and Humanitarian Assistance U. S. Agency for international development is of interest. According to it, in theoretical terms, the critical difference between PPs and CSOs is that PPs operate to get state power, while CSOs do not pursue this goal. Nevertheless, the above-mentioned scholars note that in practice in the modern world this difference is so blurred that it is difficult to separate CSOs and PPs.

This way, B. Mexhuani and F. Rrahmani support the inclusion of PPs in CSIs arguing that they clearly formulate and generalize the interests of a particular group (or groups). By participating in democratic elections, they delegate representing the interests of these groups to official political representatives and institutions [5].

In view of the above, in the process of studying the finances of the CS, we consider it necessary to expand the existing list of CSIs, provided in the Procedure, and include PPs.

However, we should emphasize that the CS cannot help to solving all state problems, as such an opinion is not productive nor helpful to the study. The point here is not only that today many countries (including Ukraine) suffer not so much from the underdevelopment of the CS, but from its pathological development, which, as P. Sytnyk argues, means its subordination to the state and neglect of common interests to satisfy private ones [28, p. 57]. Furthermore, also in the fact that the foundations of the CS are formed by the concept of democracy, which in itself has a number of negative consequences and as a result 
leads to the existence of such a pathology of development. French researcher and public figure Alexis de Tocqueville pointed out the presence of a number of shortcomings of democracy, which affect the development of the CS, in the 19th century. In his opinion, the shortcomings were the following [31]:

- envy as an exceptional product of democratic institutions, as it leads to the desire for equality among people;

- non-admission of worthy people to power, because "democracy always lacks the ability to elect worthy people, it lacks the desire and inclination to do so";

- corruption, which is characteristic of all types of political regime, but, as A. de Tocqueville acknowledges, it is in democracies that those in power are always suspected of committing certain crimes, as a result of which, in an attempt to win the support of the people, they provide support for crimes, in which they are accused;

- subjugation of the majority, which makes the individual characteristics of the person indistinct.

These shortcomings, characteristic of CS, are reflected in the economics, as their existence affects the level of the abovementioned elements of economic freedom, including equality and protection of all forms of ownership; economic freedom of various subjects in the choice of forms and implementation of entrepreneurial activity; freedom and voluntary work.

In our opinion, the shortcomings of the existence of CS and the previously identified shortcomings, which have signs of economic freedom in Ukraine, can be eliminated with a developed network of CSOs designed to socialize individuals and instil in them democratic manners and ways of thinking. This thesis was confirmed by a study carried out by French scientist A. Raymond, who argued that the social preservation of freedom requires freedom of association and a large number of associations of citizens on a voluntary basis [27].

The value of NGOs for the society is revealed through the functions they perform. There are many approaches to their classification. French civil society researcher Alexis de Tocqueville was one of the first to disclose the value of the existence of voluntary public associations for society [17, p. 255-256]. He pointed out two main functions of public organizations, namely:

1. Semiotic function means the intellectual development and improvement of human feelings of individuals by creating appropriate conditions for free interpersonal communication of public organization members;

2. Comparison of power, government, and state with the freedom of an individual through groups of common interest or through public activity, the purpose of which is the common good of the general public.

We may state that this approach to defining the functions performed by CSIs is not only still relevant, but also raises the economic component to a new level. Thus, in today's globalized world, an important part of intellectual development involves the development of the individuals in the economic sphere, because economic and financial literacy occupies a prominent place in their lives. First of all, this applies to those who are engaged in production, because the personal financial and economic literacy of those employed in this area significantly depends on the specifics of the formation and initial distribution of financial resources in the economy. This also applies to those employed in the non-productive sector, including those employed in CSOs. The function of comparing power, government and the state with the freedom of an individual resonates with the features of CS, which are inherent in the economy (equality and protection of all forms of ownership; freedom and voluntariness based on free choice of forms and types of work; economic freedom of citizens and their associations, other subjects of economic relations in the choice of forms and implementation of entrepreneurial activity).

The former Soviet Union recognized the existence of two functions of the public organizations. These functions were legally enshrined at the level of the USSR constitution. Such functions were:

1. participation in solving public issues;

2. direct satisfaction of individual, personal interests and needs of members of the organization and some of their rights [18]. However, in view of the declarative status of the existence of the public organizations themselves in the USSR, and the role of the state in solving problems at all levels of society, talking about the actual realization of the functions of the public organizations, is pointless.

With the development of science and research methods, the number of functions of pubic organizations that have been allocated by scientists has increased. Most researchers agree that public organizations perform four main functions, which can be divided into two groups $[15 ; 36]$ :

1. The functions aimed at improving the system of power in the state:

A) opposition function (limitation of excessive centralization of state power by responding to decisions of state authorities, appealing to public opinion, creation of alternative proposals, etc.);

B) creative function (development of various programs and diversification of services provided by NGOs).

2. The functions aimed at satisfying the interests of members of organizations:

A) a protective function (protecting the interests of participants from state structures by setting requirements, forming applications, identifying legislative initiatives, providing direct material and psychological assistance, as well as such radical methods as acts of public disobedience, rallies, strikes, hunger strikes, protests, picketing, etc.) ;

B) function of assistance (assistance in solving personal problems of members through the authorities).

In our opinion, as in the case of the functions allocated by $A$. de Tocqueville, within each of the four abovementioned functions of the public organizations, we can distinguish an economic component. Thus, the economic component of the opposition function of public 
organizations will be manifested, for example, in the participation of CSIs in the budgeting process (which is practiced in many economically developed countries), in economic forums, conferences, congresses with government representatives, etc.; the economic component of creative function is in CSI's involvement in joint public councils, for example, when creating strategies for social and economic development of the state and individual regions (widely used in the process of forming the Development Strategy 2020 in Ukraine). The economic component of the second group of functions, namely those aimed at satisfying the interests of members of organizations, is self-evident, because the protection of interests and assistance in solving personal problems today are mostly associated with certain social and economic problems of CSI members and their solutions.
There are other approaches to defining the functions performed by the public organizations. Thus, some scholars additionally add educational, staffing, integration, communicative, control, human rights, social control, organizational, economic, financial, logistical, informational, normative, etc. [4; 10; 23, p. 26]. It is believed that these functions (additional) are not independent, but derivative of the basic ones and their allocation is not mandatory. However, given the interconnections and interdependencies of the CS itself and the economy, they should be distinguished not as separate functions, but as a separate unit, which together with the social element serves as the socio-economic base for the remaining functions of the public organizations.

In this way, the functions performed by the Ukrainian public organizations could be schematically shown as follows on the fig. 1 .

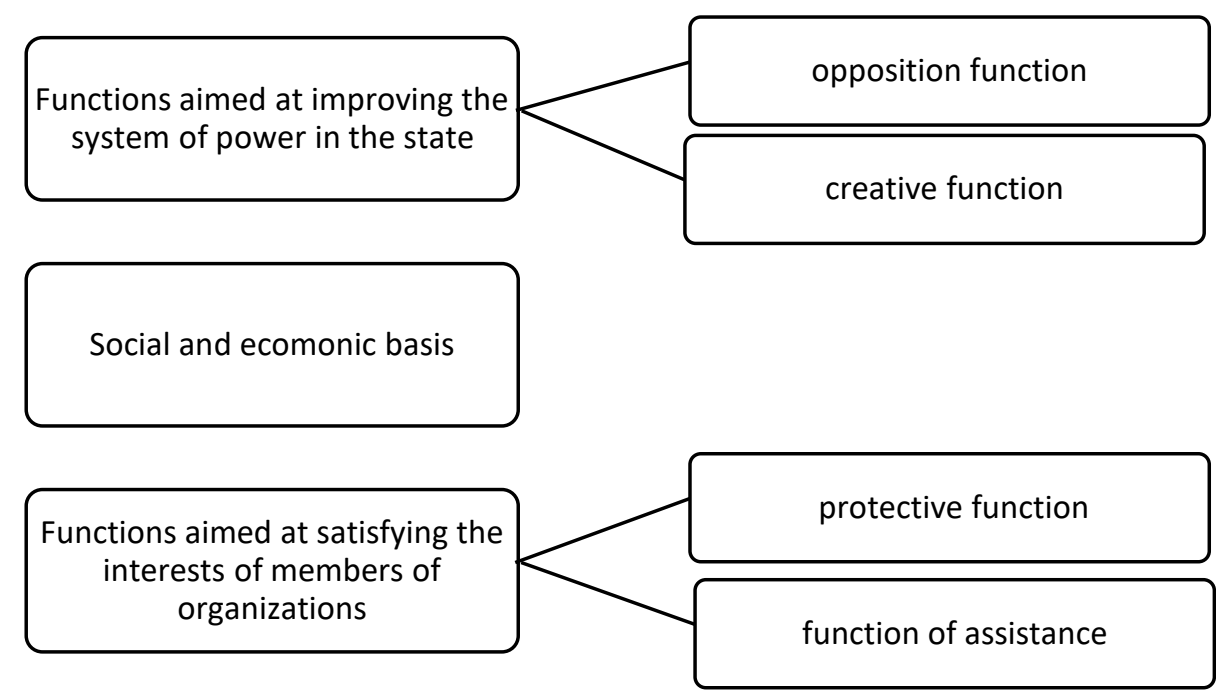

Figure 1 - Functions performed by CSI and their social and economic basis

Source: compiled by the author

Each NGO sets a number of tasks and objectives. Therefore, their activities are aimed at the solution of these tasks. The list of such tasks is enshrined in the charter of the organizations and depends on the specifics of their activities. However, based on the above-mentioned definitions of the essence of the public organizations and their functions, it is possible to form groups of tasks facing the NGOs. Thus, in our opinion, public organizations are called to perform the following tasks [30]:

- realization of rights and freedoms of citizens;

- satisfaction and protection of common interests of citizens;

- supply of resources, provision of services to citizens;

- alleviating suffering of the poor;
- achievement of social or political goals;

- protection of the environment;

- community development.

It should be noted here that in modern society the opposition function (Fig. 1) is the most important, because it helps to highlight the content of the existence of CSOs in this society. Moreover, it means that CSOs are institutions independent of the State and the will of the authorities.

Schematically, the interaction of the sphere of CS (as a sector expressed by CSIs) and such spheres as the State, Business and Family is presented in Fig. 2, which demonstrates the approach of the London Center for Civil Society. 


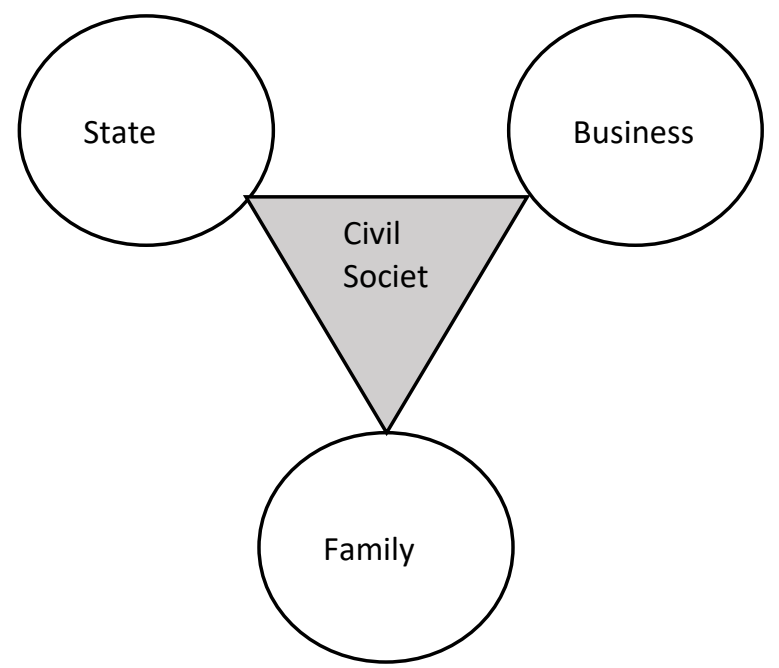

Figure 2-CS as an intermediate sphere (Model of the London Center for Civil Society)

Source: [7]

As we can see from Fig. 2, the CS occupies an intermediate sector between the State, Business and the Family. Thanks to this location the interests of the other three spheres are articulated, but it is the CS that remains separated from them.

Many scholars believe that the implementation of the CSIs tasks is based on the principles of non-profit activity (which underlies the activities of all CSIs). Such principles include economic and legal separation, self-sufficiency and financial responsibility [14, p. 94]. It is important to note that these principles significantly distinguish non- profit organizations from business entities, which are based on completely different principles [12].

Around the world, there are a number of organizations that determine the principles of formation and operation of CSOs. Such organizations are the Caux Round Table for Moral Capitalism (hereinafter - Round Table), Bureau of Democracy, Human Rights, and Labor of the USA, OSCE, and various non-governmental platforms (hereinafter NGOs). We have generalized their approaches to the selection of the principles of formation and operation of CSIs are presented in Fig. 3.
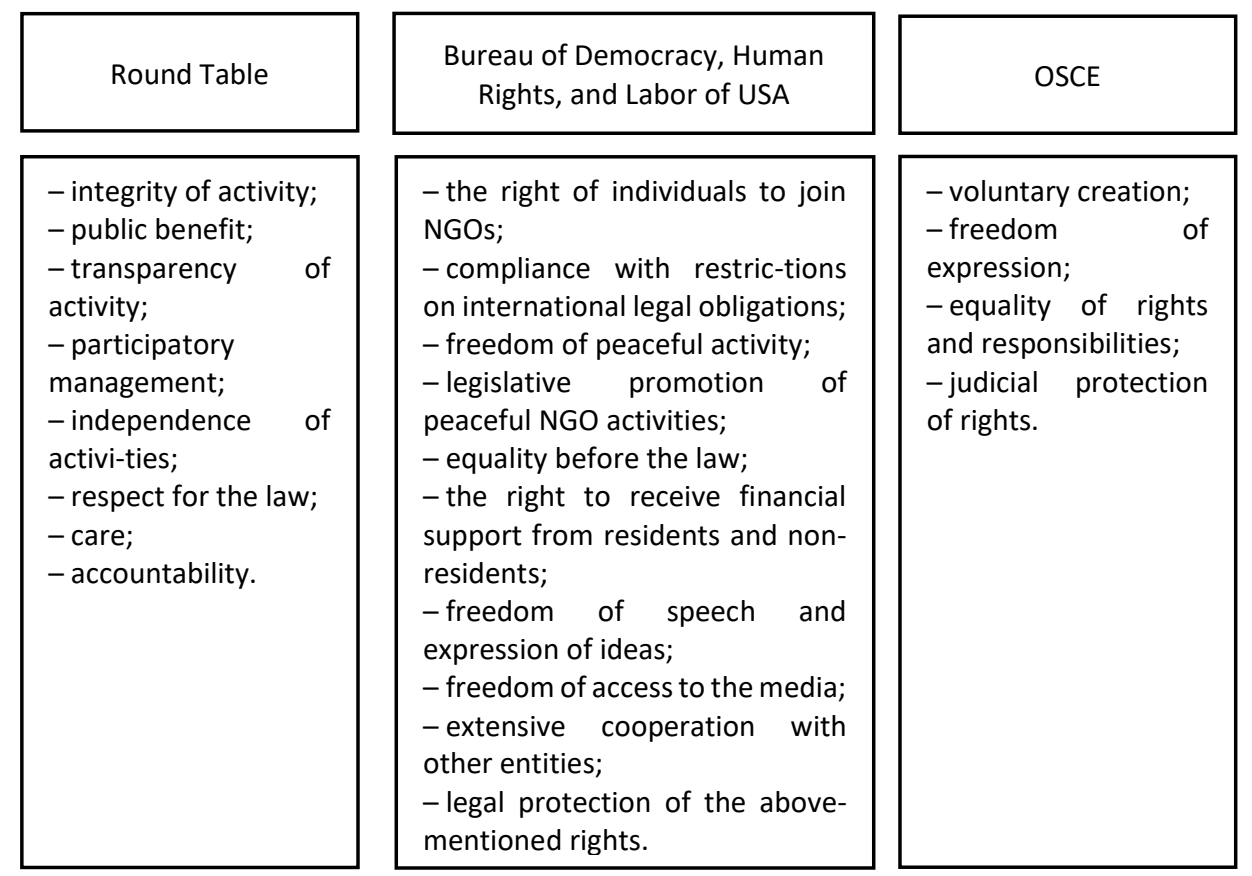

NGO platforms

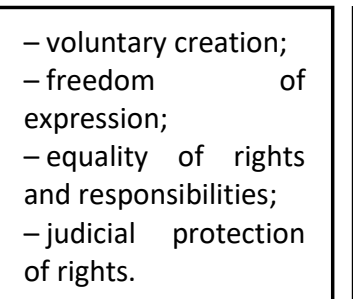
- accountability;
- cooperation and
collabo-ration;
- focus on human
rights;
- increase local
capacity.

Figure 3 - Principles of creation and activity of NGOs of leading international organizations

Source: generalized by the author on the basis of $[1 ; 2 ; 6 ; 8]$ 
Visualization of the principles of NGOs (Fig. 4) makes it possible to identify the principles that are most important for NGOs, as they are common to all researched organizations. Such principles (in one interpretation or another) are the principles of voluntary creation; focus on public benefit; cooperation with other entities to achieve the goal; accountability; equality of rights and freedoms; and legal protection of activities.

Conclusions. Institutions of civil society are voluntary, self-governed organizations of a formal or informal nature that unite individuals and legal entities that believe in the same idea or activities not connected to receiving profit. All institutions of the civil society have special functions, perform, fundamental principles of establishing and activities, which make them differ from other similar organizations. At the same time, as organizations that represent the interest of the population and are as close as possible to the population (because their founders and participants are representatives of the population), they are dynamic and reflect the mood of the society and the general state of society and economy. Moreover, their development can go ahead of the general state of development of society, "pulling" it to higher level. The development of the civil society has created significant economic and social effects in the developed countries of the world. In the economic sphere, they play an important role in the formation of GDP and GRP, create additional jobs, are innovative and attract domestic and foreign investment. Their contribution to the development of the social sphere is characterized by representing the interests of members and the population in general, their protection, promoting the education of the population and so on.

This effect should be the same in Ukraine, however, it will be very long before it will be so. The reason for the development of this issue lies in the shortcomings of the civil society of Ukraine due to the hybridity of its development. These shortcomings of the civil society could be eliminated by a quality and effective strategy of promoting the development of civil society on the state level and activity of civil society institutions among the population.

\section{References:}

1. Bureau of Democracy, Human Rights, and Labor, U. S. Department of State (2006). Guiding Principles on Non-Governmental Organizations. Retrieved from: https://2001-2009.state.gov/g/drl/rls/77771.htm [in English].

2. Caux round Table. Principles For non-governmental organizations. Retrieved from: http://docplayer.net/25467969-Principles-for-nongovernmental-organizations.html [in English].

3. Deepa, N. (2000). Voices of poor. Can Anyone hear us? Oxford University Press. Retrieved from: http://siteresources.worldbank.org /INTPOVERTY/Resources/335642-1124115102975/1555199-1124115187705/ch4.pdf [in English].

4. Kakkad, J. (2011). Discover the Functions of NGOs. Retrieved from: http://ezinearticles.com/?Discover-the-Functions-ofNGOs\&id=5680777 [in English].

5. Mexhuani, B., Rrahmani, F. (2017). The relationship between Political Parties and Civil Society. Journal of Political Sciences and Public Affairs, 5 (4), 295. Retrieved from: https://www.omicsonline.org/open-access/the-relationship-between-political-parties-and-civilsociety-2332-0761-1000295-95421.html [in English].

6. OSCE (2004). Fundamental Principles on the Status of Non-governmental Organizations in Europe. Retrieved from: https://www.osce.org/ru/odihr/37859 [in English].

7. Paffenholz, T., Spurk, C. (2006). Civil Society, Civic Engagement, and Peacebuilding. Social Development Papers. Retrieved from http://siteresources.worldbank.org/INTCPR/Resources/WP36_web.pdf [in English].

8. Principles and Recommendations for International NGO Participation in Haiti Recovery, Reconstruction and Development. Joint Paper of NGO Platforms: Brazil, Canada, Chile, Europe, France, Spain, and the United States. Retrieved from: https://reliefweb.int/sites/reliefweb.int/files/resources/64BCF3129AAE7BEF492576F8000831A0-Full_Report.pdf [in English].

9. Salamon, L. M. (2000). Putting The Civil Society Sector On The Economic Map Of The World. Annals of Public and Cooperative Economics, 81, 167-210. Doi: 10.1111/j.1467-8292.2010.00409.x [in English].

10. Skjelsbaek, K. (1975). International Nongovernmental Organizations and their Functions. A.J.R. Groom and Paul Taylor (Eds). Retrieved from: http://www.laetusinpraesens.org/docs/functun.php [in English].

11. Beliaieva, M. V. (2014). Civil society institutions in the mechanism of realization of the political function of the state of Ukraine. Naukovyi visnyk Mizhnarodnoho humanitarnoho universytetu, 9-2, 1 [in Ukrainian].

12. Verkhovna Rada of Ukraine (2003). Economic Code of Ukraine (Act No. 436-IV, January 16). Retrieved from: http://zakon4.rada.gov.ua/laws/show/436-15/print1359043105696249. [in Ukrainian].

13. Hrabovskyi, V., Mishchan, O. (2011). Ways of improvement of the interaction of public authorities with civil society institutions. Actual problems of public administration, 1 (41), 361-365 [in Ukrainian].

14. Dekhtiar, N. A., Liuta, O. V. \& Pigul, N. G. (2011). Financial mechanism of business entities. Sumy: University book [in Ukrainian].

15. Dziubko, I. S. (1998). Politology: course book. Kyiv: High school. Retrieved from: http://politics.ellib.org.ua/pages-241.html. [in Ukrainian].

16. Ziatkovskyi I. (2015). Financial motivation of socio-economic organizations. World of finance, 2 (3), 132-133 [in Ukrainian].

17. Karas, A. (2003). Philosophy of civil society in classical theories and non-classical interpretations. Lviv: Publishing center of LNU named after I. Franko. [in Ukrainian].

18. Authorities of the USSR (1977). Constitution (basic law) of the Union of Soviet Socialist Republics. (Act. No. n0001400-77, October 7) Retrieved from: http://zakon4.rada.gov.ua/laws/show/n0001400-77/print1360001878653288. [in Ukrainian].

19. Kuprii, V. O. (2007). Civil society organizations as subjects of state policy making (Abstract of PhD Thesis). Public administration. Kyiv: National Academy of Public Administration under the President of Ukraine. [in Ukrainian].

20. Lotiuk, O. (2014). The essence and classification of civil society institutions. Naukovyi visnyk Uzhhorodskoho natsionalnoho universytetu. Seriia: PRAVO, 29, 1, 32 [in Ukrainian]. 
Електронне наукове фахове видання з економічних наук "Modern Economics», №22 (2020), 99-107 https://modecon.mnau.edu.ua | ISSN 2521-6392

21. Mazur, O. (2006). Civil society institutions as a factor of modernization of the electoral system. Political management, 5. Retrieved from: http://dspace.nbuv.gov.ua/bitstream/handle/123456789/9652/05-Mazyr.pdf?sequence=1. [in Ukrainian].

22. Moshynskyi, R. (2013). Civil society institutions in Ukraine: socio-legal orientation of political processes and their impact on national security. Visnyk natsionalnoi akademii derzhavnoho upravlinnia, 2, 184-192 [in Ukrainian].

23. Pashchenko, V. O. (2004). Non-governmental organizations: prospects for development (research methodology). Tрибуна, 11, 26-27 [in Ukrainian].

24. Cabinet of Ministers of Ukraine (2008). About the statement of the Order of assistance to carrying out public examination of activity of executive authorities. (Decree No. 976, November 5). Retrieved from: http://zakon2.rada.gov.ua/laws/show/976-2008-\%D0\%BF. [in Ukrainian].

25. Verkhovna Rada of Ukraine (2001). About the political parties in Ukraine. (Act. No. 2365-III, April 5). Retrieved from: http://zakon2.rada.gov.ua/laws/show/2365-14 [in Ukrainian].

26. Ermolaev, A., Gorelov, D., Kornievskii, O. (2012). About the state of development of the society in Ukraine. Kyiv: NISS. [in Ukrainian].

27. Ramon, A. (1990). Democracy and totalitarianism. Retrieved from: http://www.e-reading-lib.org/book.php?book=89783. [in English].

28. Sytnyk, P. K. (2002). Civil society and the State: features of their interaction. Strategic panorama, 4, 57 [in Ukrainian].

29. Solyar, S. (2013). Civil society institutes. The forum of right, 1, 933-938. [in Ukrainian].

30. Tkachuk, I. (2016). Financial support for the activities of NGOs in Ukraine (PhD Thesis). Money, finance and credit. Lviv: Ivan Franko Lviv National University. [in Ukrainian].

31. Tokvil, A. (1999). About the democracy in America. Kyiv: Universe.

32. Uvarov, A. (2009). The tendency of development of the civil society in Russia. Russian justice, 7, 2 [in Russian].

33. Usvatov, I. S. (2009). For the question about the structure of the civil society: defining the civil society institution. Gaps in Russian legislation, 4, 82-83 [in Russian].

34. Fedorenko, V., Kagliak, Ja. Institutes of civil society and the institute of public organizations in Ukraine: theoretical-methodological and normative-design aspects. Retrieved from: https://helsinki.org.ua/2009/05/instytuty-hromadyanskoho-suspilstva-ta-instytuthromadskyh-orhanizatsij-v-ukrajini-teoretyko-metodolohichni-ta-normoproektni-aspekty. [in Ukrainian].

35. Chernoivanenko, A. (2015). Political parties: their role and functions in modern state-building processes in Ukraine. Theory and practice of public administration, 3 (50). Retrieved from: http://www.kbuapa.kharkov.ua/e-book/tpdu/2015-3/doc/1/14.pdf. [in Ukrainian].

36. Iurii, M. F. (2006). Politology. Course book. Kyiv: Dakor. Retrieved from: http://www.ebk.net.ua/Book/political_science/ uriy_politologiya/part4/1104.htm. [in Ukrainian]. 